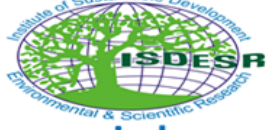

www.isdesr.org

\title{
HYDROGEOCHEMICAL INTERACTION ON GROUNDWATER REGIME OF BAGAD RIVER GAJRAULA, UTTAR PRADESH- A CASE STUDY
}

\author{
Jiban Singh $\mathbf{M}^{1}$, Parveen Garg $^{2}$ and Vijay Goel ${ }^{3}$ \\ ${ }^{1}$ Dept. of Environmental Sc., Swami Shraddhanand College, University of Delhi, Delhi, India. \\ ${ }^{2}$ Department of Botany, Swami Shraddhanand College, University of Delhi, Delhi, India. \\ ${ }^{3}$ Department of Physical Sciences, Jawaharlal Nehru University, Delhi, India \\ Corresponding Author Email: jiban@ss.du.ac.in
}

How to cite this paper:

Jiban Singh M, Parveen Garg and Vijay Goel (2021) Hydrogeochemical Interaction on Groundwater Regime of Bagad River Gajraula, Uttar Pradesh - A Case Study, Journal of Global Resources, Vol. 07 (02)

\section{DOI:}

10.46587/JGR.2021.v07i02.006

Received: 21 March 2021

Reviewed: 10 April 2021

Accepted: 11 May 2021

Final Accepted: 22 May 2021

\begin{abstract}
Suitability study for the use of groundwater for domestic and irrigation purposes was carried out in the catchment of Bagad River sub basin in the Upper Ganga basin, Gajraula, Uttar Pradesh. Fifteen samples of the study area were collected and analyzed for physicochemical and heavy metal parameters. According to physicochemical analysis groundwater samples were categorized into different classes. It was observed that 80 percent of groundwater hardness found to be due to presence of only non-carbonate or "permanent" hardness caused by the combination of $\mathrm{Ca}^{2+}$ and $\mathrm{Mg}^{2+}$ with $\mathrm{SO}_{4}{ }^{2-}, \mathrm{Cl}$ and $\mathrm{NO}_{3}{ }^{-}$which made it very difficult to rejuvenate and may cause due to leaching of ions followed by discharge of industrial waste activities through the River. As per the TDS concentration in the study area, 50 percent of the groundwater samples are categorized as brackish water and 100 percent of the River samples are categorized as brackish cum saline water; confirmed surface and groundwater were unified through the hydrological cycle. The concentration of TDS, BOD and Colour in groundwater were directly proportional to each other, confirmed that the groundwater was contaminated by industrial activities at Gajraula city as well as nearby villages. The Concentration of $\mathrm{NO}_{3}{ }^{-}$in groundwater is much higher than its concentration in River, indicated possible leaching of industrial and agricultural chemicals. In groundwater, 30 percent samples of $\mathrm{SO}_{4}{ }^{2-}$ concentration was beyond the permissible limit of the Indian standard (400 $\mathrm{mg} / \mathrm{l})$ suggested due to the action of leaching and anthropogenic activities. Heavy metals except As, Fe, $\mathrm{Mn}, \mathrm{Pb}$ and $\mathrm{Zn}$ were found below the detectable limit in all surface and groundwater samples. However, comparison between concentration of elements in groundwater samples shows Heavy Metal abundance in the order of Fe (10) $>M n(10)>P b(4)>Z n$ (3) $>A s(1)>C u(B D L)>C r(B D L)>N i(B D L)>C d(B D L)$, indicating lithogenic origin of $\mathrm{Fe}$ in groundwater.
\end{abstract}

Keywords: Bagad River, Contamination, Effluent Discharge, Groundwater and Industries. 


\section{Introduction}

Industrialization, deforestation and urbanization have twisted risky impacts on the biosphere due to the discharge of industrial, municipal and agriculture wastes containing toxic materials like pesticides, insecticides, fertilizers residues and heavy metals, etc. Groundwater is the primary source of fresh water for various urban and rural areas. However, due to industrialization, most of the groundwater resources have been affected tremendously through in judicious discharge of partially or untreated industrial effluents on land or into a surface water body in most of the cities and industrial townships. Imprudent withdrawal of groundwater from an area and overexploited condition resulted in rapid leaching leading to contamination of groundwater with polluted water (Greenwood and Buttle, 2020).

As per the National Green Tribunal (NGT) direction on $20^{\text {th }}$ July 2020, industries must expect a complete overhaul in the manner in which permits are issued for the extraction of groundwater for commercial activities. They must ensure that all the conditions have complied with the tribunal has specifically banned the general permission for the withdrawal of groundwater, especially to the commercial entities without an environmental impact assessment. Permits must be issued for the specified quantity of water and must be monitored with digital flow meters and audited every year by third parties. Strict actions, including prosecution and blacklisting, must be taken against those who fail the audit. As per the new rules, the authorities are given three months to make water management plans for all the overexploited, semi-critical and critical areas. Around 8, 00,000 companies are falling under such areas, which have been accounting for about onethird of all 3,881 groundwater assessment units in India (Shailaja Tripathi, 2020).

Gajraula is a prominent industrial area of western Uttar Pradesh, owes its consequence to a diverse group of industries, which includes distilleries and its associated chemical units, paper, phosphate fertilizer plant, textiles, pharmaceuticals, dairy, silica and other units. Most of the rivers, streams, and drains were converted into open sewerage network systems, and the shallow groundwater regime has become more vulnerable to discharge effluent contamination. For the last four decades, due to which Bagad River has been converted into an open sewerage network system and termed as Bagad drain. Although, groundwater is the only natural resource for drinking and irrigation purposes in and around Gajraula city hence it is required to monitor regularly, and the people should be made aware of the drinking water quality.

Groundwater and surface water is an essential commodity required for survival by all the forms of life in earth. However, if the industrial effluents discharged into the water body contains toxic chemicals, hazardous compounds, bacteria's, suspended solids and non-biodegradable materials (Nasrullah et al., 2006). Despite the various measures undertaken by the Government agencies to prevent the water pollution which occurred due to the untreated or partially treated effluents are being discharged into Bagad River, as evident from groundwater quality.

Water pollution ultimately leads to health hazards directly or indirectly. Bagad River near Gajraula industrial area is the end point of discharge effluents. The water quality of Bagad River is a cause of great concern as it is worsening day by day due to discharge of effluent without adequate treatment, thus, polluting the upper aquifer through the leaching process in and around 
the industrial area. Therefore, to assess the hydrogeochemical interaction and the impact of pollution on groundwater in its aquifer is the main intent of this case study.

\section{MATERIAL AND METHODS \\ Study Area}

Gajraula city is located around $110 \mathrm{~km}$ away from Delhi on national highway nine, towards Garhmukteshwar to Amroha. Both Ganga and Bagad Rivers are situated in between Garhmukteshwar town and Gajraula city. Bagad River is just $7 \mathrm{~km}$ away from the Ganga. It has an average elevation of 258 meters (Figure 1). As per the survey, Bagad River originates from National Highway, Khyalipur (RL2) (Figure 1 and Photo 1). However, during the field visit, Bagad River was observed to have two origins and another one at Shahbazpur Dor (RL1) (Figure 1 and Photo 2). Bagad River flow parallel with the Ganga River and both meet at Agroula Kalan (RL9: N28.780298, E78.232338) (Figure 1 and Photo 11) and ends at Paurara Ahtmali (RL15: N28.51517, E78.29123), Uttar Pradesh (Figure 1 and Photo 25).

The distance between the two origins [Left Origin (RL1): N28.825270, E78.2154920 and Right Origin (RL2): N28.79795, E78.205048] is $3.19 \mathrm{~km}$ approximately (Figure 1). The approximate stretch length of Bagad River from Left origin to confluence is about $64.5 \mathrm{~km}$ (Figure 1). However, after Paurara village this River is not traceable and Riverbed after this location is used as an agricultural field. Therefore, there is no direct impact of Bagad River into River Ganga. However, during monsoon season Bagad River discharge may meet with the River Ganga as the minimum distance between the last traceable point of Bagad River and River Ganga is $4.63 \mathrm{~km}$. (Figure 1).

\section{Methodology}

Field research was performed to assess the water quality of Bagad River and its impact on groundwater quality. The monitoring team consisting of officials from the Department of Environmental Science and Botany, Swami Shraddhanand College, University of Delhi, Delhi, and the Department of Physical Sciences, Jawaharlal Nehru University, Delhi, India, monitored the entire stretch $(64.5 \mathrm{~km})$ of this River consisting at 15 sampling locations of groundwater and River (Figure 1).

The study was conducted in the dry season of March 2021. Total of 15 samples (10 for groundwater and 5 for River) were collected. Most of the groundwater samples were obtained directly from the hand pumps and bore wells after allowing the water to run for at least 5 minutes to stabilize the variation in electrical conductivity and temperature (Reimann et al., 2003). Samples were collected in high-density polyethylene bottle and preserved with applicable reagent as well as brought to the laboratory to store at $4^{\circ} \mathrm{C}$ temperature in order to avoid any significant chemical alteration or change due to microbial activities (APHA, 2005). For each sample, grab sampling was done, details of location and date and time of sampling were recorded, appropriately labeled, and transported to the laboratory. All samples were analyzed in the concerned laboratories of Universities. 


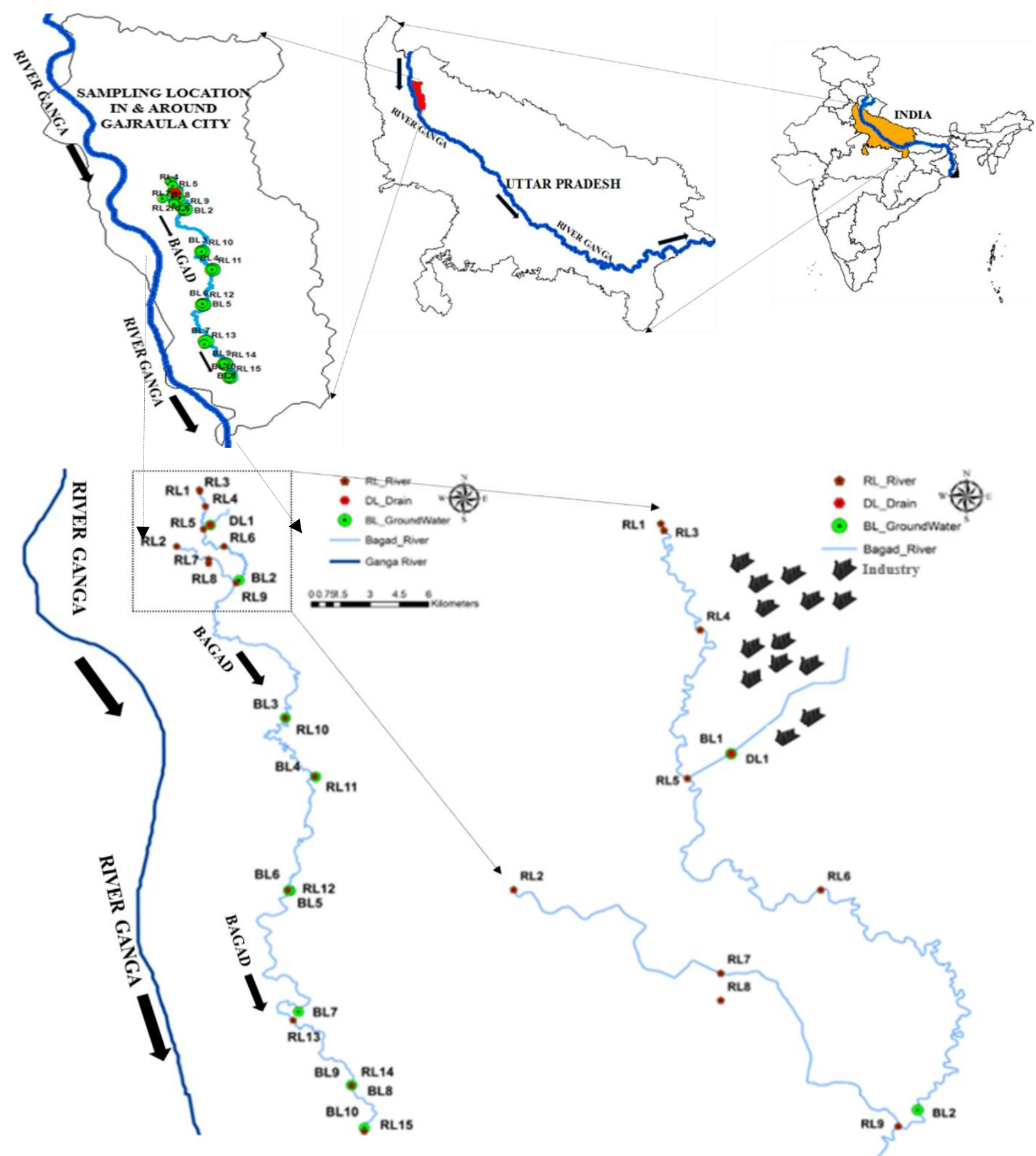

Figure 01: Drainage system, sampling locations of Bagad River along with Ganga River.

\section{Result and Discussion}

Out of the 15 locations, left origin cum first location at Shahbazpur Dor (RL1) (Figure 1 and Photo 1) and right origin cum second location at Khyalipur, NH-9 (RL2) (Figure 1 and Photo 2) were found dry. These left and right origins are just below the railway track at $\mathrm{NH}-9$ upstream of the industrial area, respectively. As per local people, the River at these natural origins has been dry for the last 25 years. The third location at Shahbazpur Dor (RL3) was also found dry and adjacent to the bio-compost yard of M/s Jubilant Life sciences (Distillery) (Figure 1 and Photo 3). The fourth location at Tigriya Khadar (RL4) was also found dry, which is located upstream of the industrial cluster (Figure 1 and Photo 4). The fifth location at Tigriya Khadar (RL5) was observed with Journal of Global Resources, July 2021, Volume 07 (02) Jiban Singh M, Parveen Garg and Vijay Goel Page 57 | 13 
stagnant water (Figure 1 and Photo 5). The sixth location at Sultanpur Ther (RL6) was also found with stagnant water. Seventh $(R L 7)$ and eighth $(R L 8)$ locations at Sultanpur Ther were found dry (Figure 1, Photos 9 and 10). The ninth location (Agroula Kalan, RL9) is the meeting point of both the origins of Bagad River and found stagnant water body. Up-streams of this location also have stagnant and dry suggested that stagnant water bodies at this location may be due to agricultural residue (Figure 1 and Photo 11). Further, the tenth and eleventh locations at Karan Khal (RL10) and Shakrouli (RL11) were observed stagnant water bodies with rich aquatic floras and faunas (Figure 1, Photos 13 and 15).

Also, twelfth, thirteenth, fourteenth and fifteenth at Shakargadhi (RL12), Tarauli $(R L 13)$, Gangeshwari (RL14) and Paurara Ahtmali (RL15) were found dry during the visit (Figure 1, Photos 17, 20, 22 and 25). After Paurara village, this River is not traceable due to Riverbed up to Ganga is used as an agricultural field.

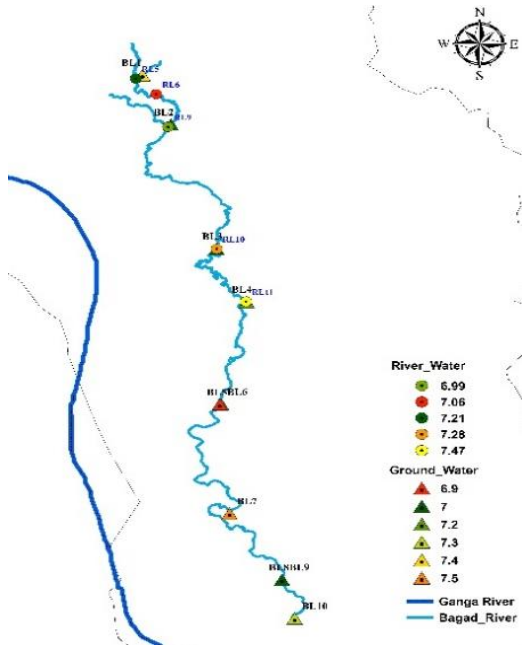

Figure 2: Variation of $\mathrm{pH}$ in River and Groundwater

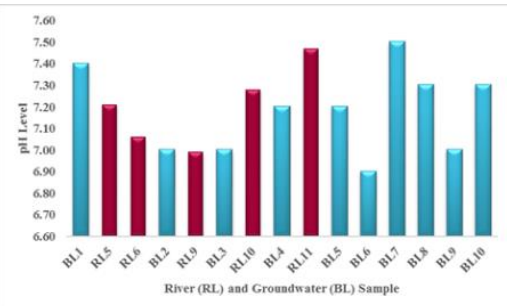

Figure 2a: Bar diagram of $\mathrm{pH}$ values in Samples

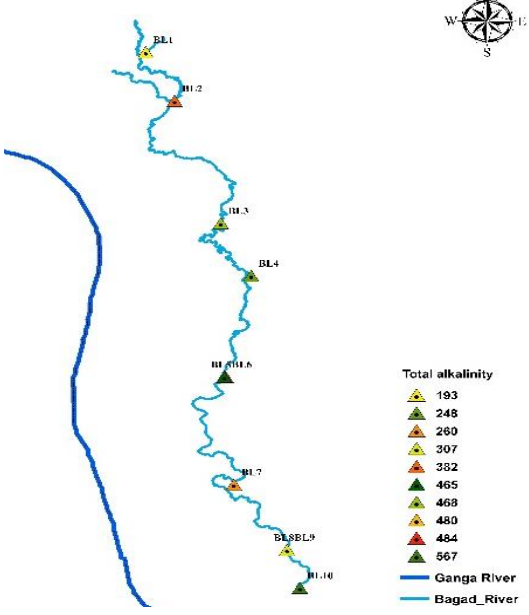

Figure 3:Variation of Total Alkalinity in Groundwater

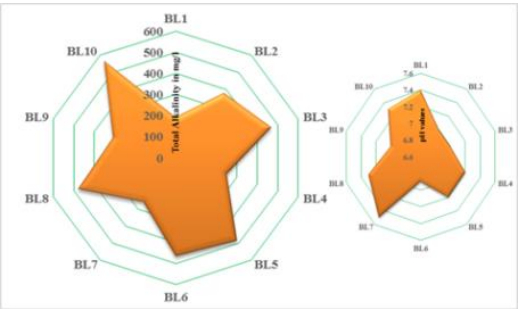

Figure 3a: Total Alkalinity with associate to $\mathrm{pH}$ values in Groundwater

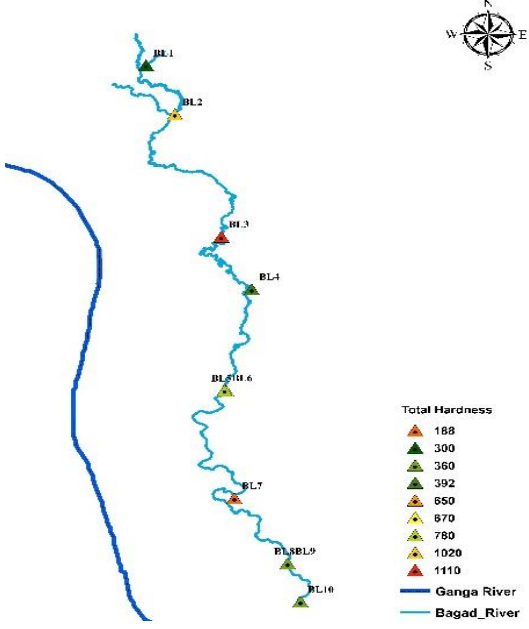

Figure 4: Conc. of Total Hardness in Groundwater

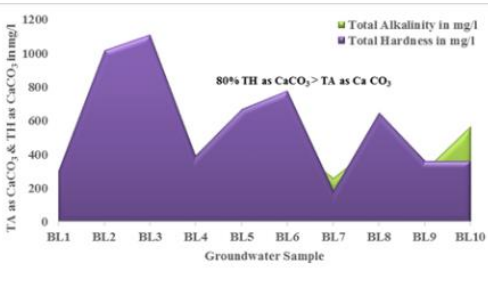

Figure 4a: Relation between Total Hardness and Total Alkalinity in Groundwater

Access to safe drinking water remains an urgent necessity, as 30 percent of urban and 90 percent of rural households still depend entirely on untreated surface or groundwater (Kumar et al., 2005). While access to drinking water in India has increased over the past decade, the tremendous adverse impact of unsafe water on health continues (WHO/UNICEF, 2004). It is now generally recognized that the quality of groundwater is just as important as its quantity. 
In this current study, the $\mathrm{pH}$ values of River water and groundwater samples were found slightly acidic to neutral, and it varies from 6.99 to 7.50 and 6.90 to 7.54 , respectively (Figure 2). However, pH values lie within the acceptable limit (6.5-8.5) of Indian standards (BIS: 2012) (Figure 2a). The alkalinity is referred to as the acid-neutralizing capacity of the water and expression of buffering capacity. The basic species responsible for alkalinity in water are $\mathrm{HCO}_{3}{ }^{-}$, $\mathrm{CO}_{3}{ }^{2-}$ and $\mathrm{OH}^{-}$(Vinod, 2012). In this study, total alkalinity values of groundwater vary from 193 to $567 \mathrm{mg} / \mathrm{l}$ and 100 percent of the samples below the permissible limit $(600 \mathrm{mg} / \mathrm{l})$ of Indian standard (BIS: 2012, Figures 3 and $3 \mathrm{a}$ ) and was found associated, proportionally with to $\mathrm{pH}$ values of the samples. The total hardness is caused primarily due to the polyvalent cations $\left(\mathrm{Ca}^{2+}\right.$ and $\left.\mathrm{Mg}^{2+}\right)$ present in water. According to Ravikumar et al., (2010) good covenant, total hardness values of groundwater greater than the total alkalinity indicates the presence of only non-carbonated hardness (NGWA, 2020). The total hardness of groundwater in the study area ranges from 188 to $1110 \mathrm{mg} / \mathrm{l}$, and 90 percent of sample values are beyond the BIS acceptable limit $(200 \mathrm{mg} / \mathrm{l})$ for drinking (BIS: 2012) (Figure 4). Similarly, 80 percent of groundwater hardness is greater than the total alkalinity indicated the presence of only non-carbonate or "permanent" hardness caused by the combination of $\mathrm{Ca}^{2+}$ and $\mathrm{Mg}^{2+}$ with $\mathrm{SO}_{4}{ }^{2-}, \mathrm{Cl}^{-}$and $\mathrm{NO}_{3}{ }^{-}$which is very difficult to remove (Figure 4a). It is very likely that groundwater hardness in this study area is caused by chemical and fertilizer industrial activities through leaching from the Bagad River.

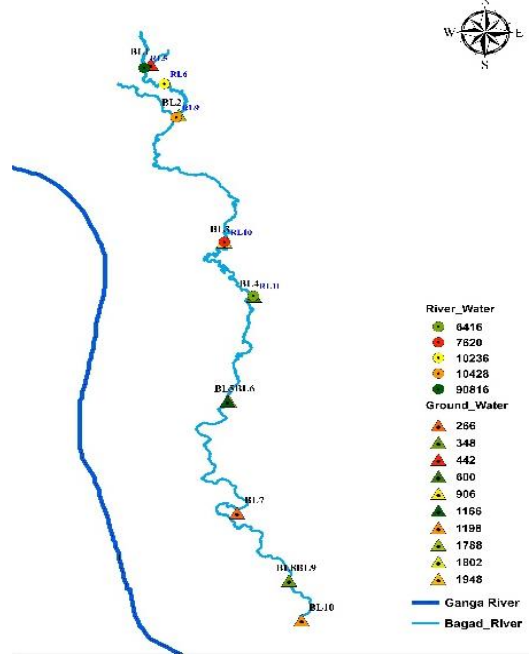

Figure 5: Variation of TDS in samples

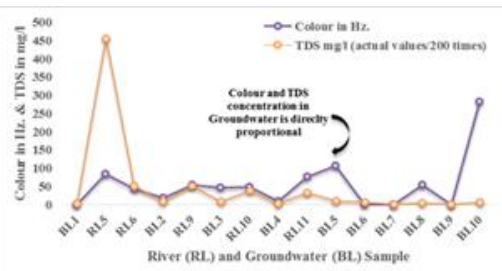

Figure 5a: Directly proportional of TDS and Colour conc. in samples
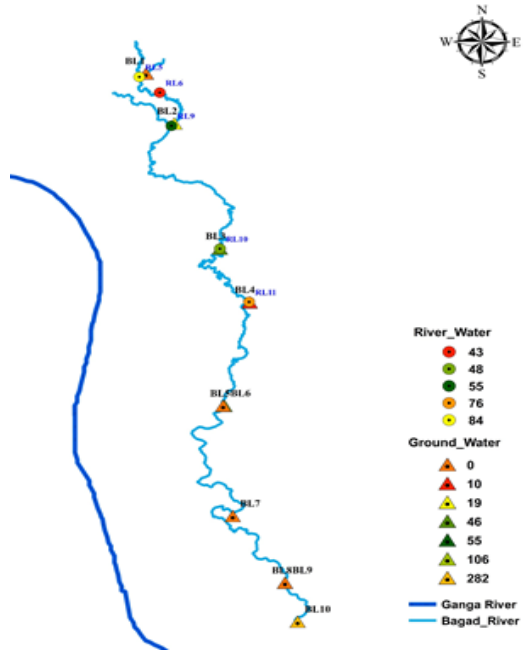

Figure 6: Colour appearance in samples

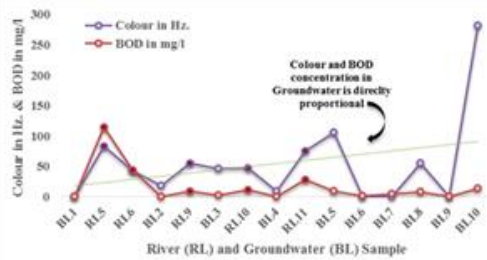

Figure 6a: Directly proportional of BOD and Colour conc. in samples.

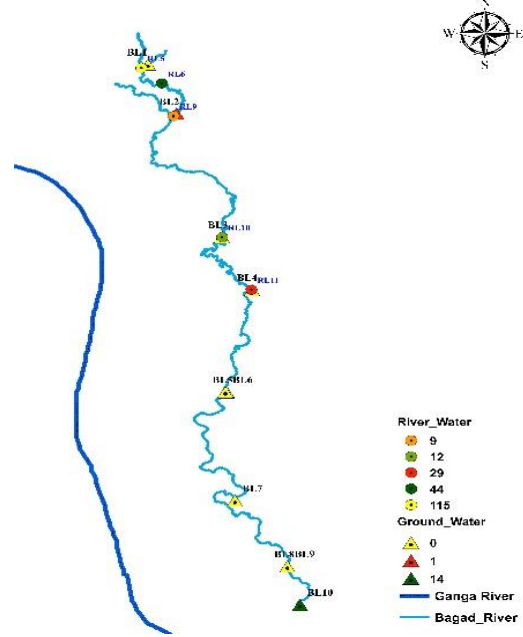

Figure 7: Variation of BOD in samples

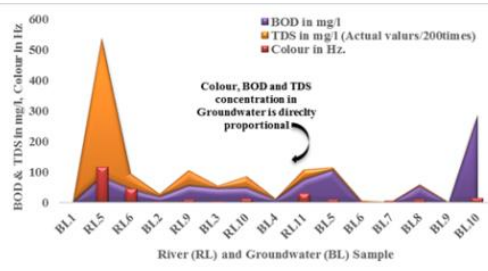

Figure 7a: Directly proportional between Colour, TDS and BOD conc. in samples. 
Electrical Conductivity (EC) measures the salt concentration and indicates ionic concentrations in the water (Ashwani and Abhay, 2014). The measured EC of groundwater varies from 484 to $3542 \mu \mathrm{S} / \mathrm{cm}$ and exceeds the permissible limit $(3000 \mu \mathrm{S} / \mathrm{cm})$ of the Indian standard in 30 percent samples (BIS: 2012). The Total Dissolved Solids (TDS) indicate the general nature of salinity of water (Ranjit and Ajit, 2004). TDS are composed mainly of $\mathrm{CO}_{3}{ }^{2-}, \mathrm{HCO}_{3}{ }^{-}, \mathrm{Cl}, \mathrm{PO}_{4}{ }^{3-}$, and nitrates of $\mathrm{Ca}, \mathrm{Mg}, \mathrm{Na}, \mathrm{K}$ and $\mathrm{Mn}$, organic matter, salt and other particles (Jain et al., 2010). TDS content is usually the main factor that determines the use of groundwater for any purpose (Nordstrom, 1987). The concentration of TDS in the River water and groundwater, ranged from 6416 to $90816 \mathrm{mg} / \mathrm{l}$ and 266 to $1948 \mathrm{mg} / \mathrm{l}$, respectively (Figure 5). Based on Freeze and Cherry,1979 classification, 50 percent of the groundwater samples in the study area are categorized as fresh water (TDS $<1000 \mathrm{mg} / \mathrm{l}$ ), and the same percentage of the River samples are categorized as brackish cum saline water (TDS>3000 mg/l) (Jiban Singh et al., 2017). However, 70 percent of the groundwater samples in this study area are beyond the acceptable limit (500 $\mathrm{mg} / \mathrm{l}$ ) for drinking (BIS: 2012). The spatial variation shows higher TDS values at Agroula Kalan, Karan Khal Shakargadhi, Shakrauli, Gangeshwari, and Paurara Ahtmali villages (Figure 5) and, if used for drinking purposes, may induce an unfavorable physiological reaction in the transient consumer and gastrointestinal irritation (Shankar et al., 2008). High concentration of TDS in the water body is from industrial sources like Silica manufacturing units (Mohit Tyagi, 2015), and in this study, the significant spatial differences between the values of TDS in groundwater at the same Riverbed aquifer would be the local impact of agricultural and industrial activities as well as may be recognized from the lithological variations in the region (Figure 5). Further, TDS above $3000 \mathrm{mg} / \mathrm{l}$ is classified as unfit for drinking and irrigation (Fetter, 1990 and Jiban Singh et al., 2012). In this study, 100 percent TDS values of Bagad River were found more than $6000 \mathrm{mg} / \mathrm{l}$ indicated contamination from anthropogenic sources.

Colour refers to the appearance of water in terms of suspended matter and turbidity. It results almost entirely from extraction of coloring (dyes, peroxides, effluent) matters and decaying organic materials (vegetation roots and leaves) in bodies of surface water and ground. Natural Colour of 10 units or less usually goes unnoticed and even in larger amounts, is harmless in drinking water (NGWA, 2020). In the present study, the Colour of River water and groundwater appeared dark brown and ranged from 43 to $84 \mathrm{~Hz}$ and 0 to $282 \mathrm{~Hz}$, respectively (Figure 6, Photos $5,8,11,13,14,15,16,18$ and 26 ), indicated 60 percent of the groundwater samples in the study area are beyond the acceptable limit $(5 \mathrm{~Hz})$ and belongs to risk for drinking (BIS: 2012). Further, the Colour appearances of River and groundwater samples were directly proportional to the values of TDS (Figure 5a), established Bagad River is contaminated by industrial effluent and interacted with groundwater. Similarly, Biochemical Oxygen Demand (BOD) is conveyed as the degree of contamination of organic matter in water (Deshmukh and Karanth, 1973) whenever there is low DO content in water, normally high BOD is observed (Drever, 1982). In this case study, BOD concentration in River and groundwater ranged from 9 to $115 \mathrm{mg} / \mathrm{l}$ and 0 to $14 \mathrm{mg} / \mathrm{l}$, respectively (Figure 7) and directly proportional to Colour and TDS (Figures 6a and 7a), showed the groundwater contaminated by industrial activities at Gajraula city and nearby villages like Agroula Kalan, Karan Khal Shakargadhi, Shakrauli, Tarauli, Gangeshwari and Paurara Ahtmali.

Concentrations of $\mathrm{NO}_{3}{ }^{-}$in groundwater originate from the atmosphere, living and decaying organisms (Basavarajappa and Manjunatha, 2015). Nitrates themselves are relatively nontoxic, but high concentrations are due to the leaching or runoff from agricultural and industrial activities 
(WHO, 2004). In this study, $\mathrm{NO}_{3}{ }^{-}$concentration in River and groundwater varies from 2.04 to 11.5 $\mathrm{mg} / \mathrm{l}$ and BDL to $41 \mathrm{mg} / \mathrm{l}$, respectively (Figure 8 ), while all samples are compiled the permissible limit (45 mg/l) of Indian standard (BIS: 2012). However, when compared with the concentration of $\mathrm{NO}_{3}{ }^{-}$in groundwater, it is much higher than the concentration in River as indicated due to leaching from industrial and agricultural activities (Figure 8a).

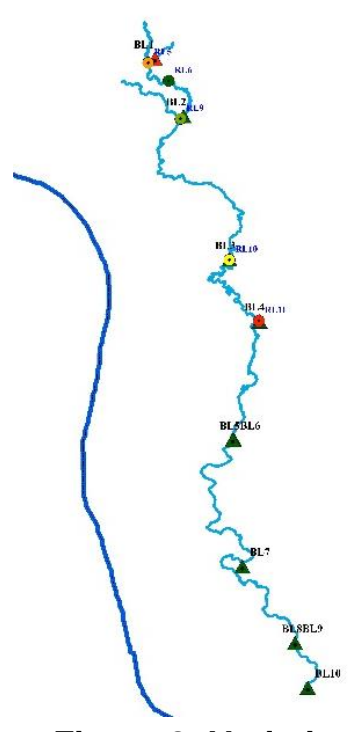

Figure 8: Variation of $\mathrm{NO}_{3}$ values in samples

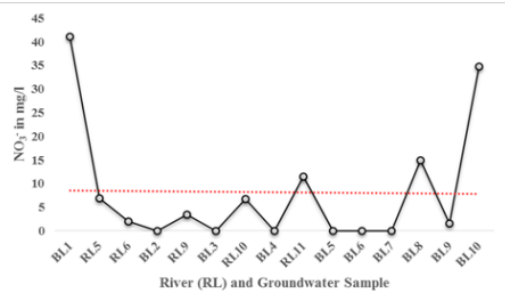

Figure 8a: Line diagram of $\mathrm{NO}_{3}{ }^{-}$values in Samples

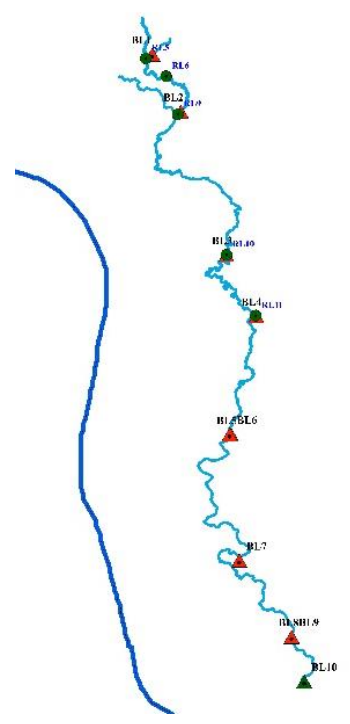

Figure 9: Arsenic conc. found in Paurara Village.

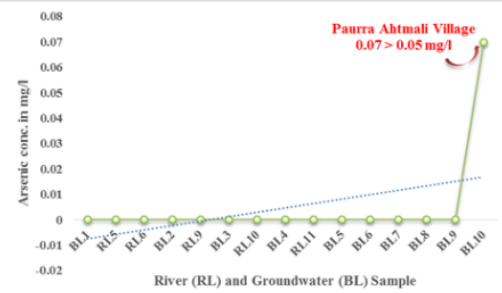

Figure 9a: Line diagram of Arsenic concentration

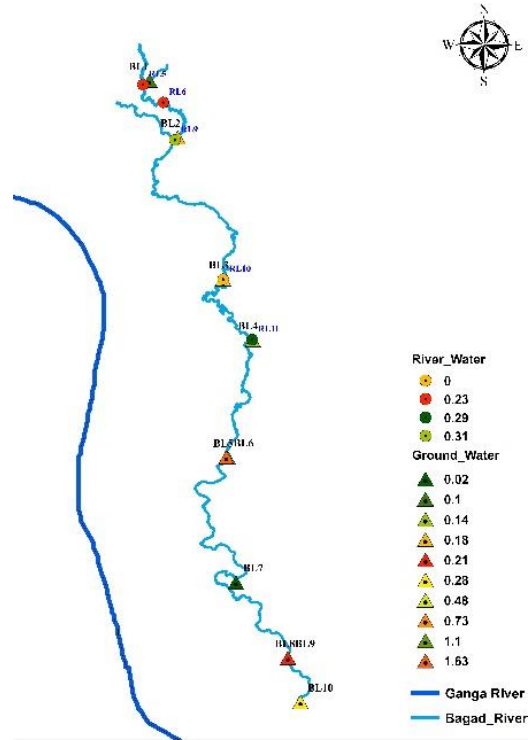

Figure 10: Manganese conc. in samples.

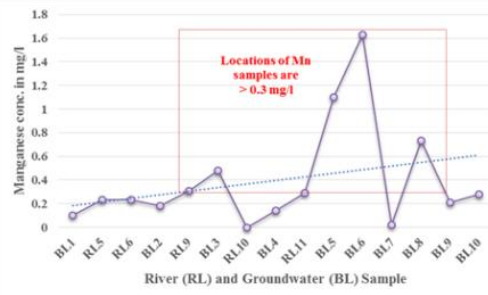

Figure 10a: Line diagram of Manganese concentration

Industries like chemical fertilizers, silica and sugar factories, etc. with anthropogenic activities are contributing factors to the Sulphate $\left(\mathrm{SO}_{4}{ }^{2-}\right)$ and Chloride $\left(\mathrm{Cl}^{-}\right)$concentrations in the groundwater and the excess of $\mathrm{Cl}^{-}$in the water is usually taken as an index of pollution and considered as tracer from groundwater contamination (Prasnath et al., 2012 and Jiban Singh et al., 2017). The $\mathrm{Cl}^{-}$concentration in River and groundwater in this study ranged from 118 to 236 $\mathrm{mg} / \mathrm{l}$ and 8 to $113 \mathrm{mg} / \mathrm{l}$, respectively and observed that all locations are below the acceptable limit (250 mg/l, BIS: 2012). However, the $\mathrm{SO}_{4}{ }^{2-}$ in groundwater generally present as $\mathrm{Ca}^{2+}, \mathrm{Mg}^{2+}$, and $\mathrm{Na}^{+}$soluble salts. A significant change in the $\mathrm{SO}_{4}{ }^{2-}$ concentration takes place with time during surface infiltration and groundwater recharge (Jain et al., 2010). In this study, the $\mathrm{SO}_{4}{ }^{2-}$ concentrations in the River samples vary from 854 to $1247 \mathrm{mg} / \mathrm{l}$ and which is beyond the permissible limit of $400 \mathrm{mg} / \mathrm{l}$ (BIS: 2012). However, $\mathrm{SO}_{4}{ }^{2-}$ in the groundwater samples vary from 0 to $884 \mathrm{mg} / \mathrm{l}$ and 30 percent of samples beyond the permissible limit of $400 \mathrm{mg} / \mathrm{l}$ (BIS: 2012) suggested contamination from anthropogenic activities. 
The aquatic environment is frequently the ultimate recipient of heavy metal pollution (Obasohan et al., 2006), and their distribution and occurrence depend on the degree of weathering and mobility during weathering and directs discharge from industrial activities (Handa, 1986 and Jiban Singh et al., 2017). The investigation of groundwater samples from the Tigriya Khadar, Agroula Kalan, Karan Khal, Shakrouli, Shakargadhi, Tarauli, Gangeshwari, and Paurara Ahtmali villages of Gajraula has thrown up some alarming statistics about the groundwater that people drink every day. In this study, the reports of heavy metals except $\mathrm{As}, \mathrm{Fe}, \mathrm{Mn}, \mathrm{Pb}$, and $\mathrm{Zn}$ remaining metals like $\mathrm{Cd}, \mathrm{Co}, \mathrm{Cr}, \mathrm{Cu}, \mathrm{Ni}, \mathrm{Sb}$, Se and $\mathrm{V}$ were below the detectable limit (BDL) in all the samples.

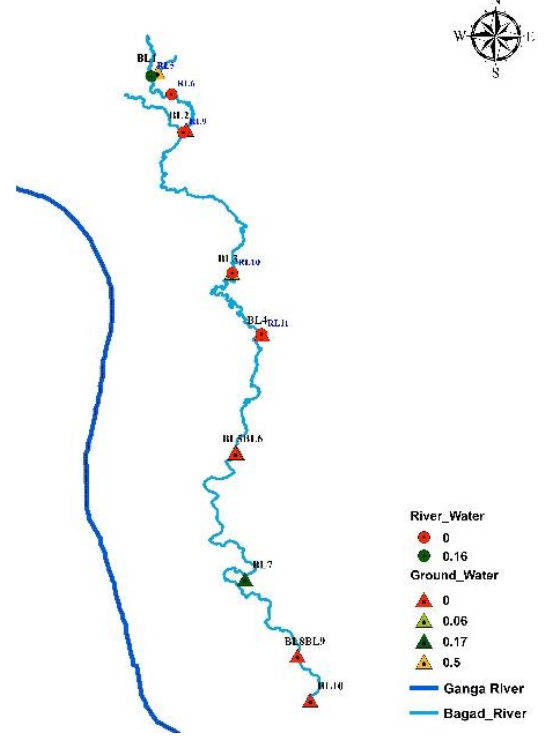

Figure 11: Zinc conc. in samples

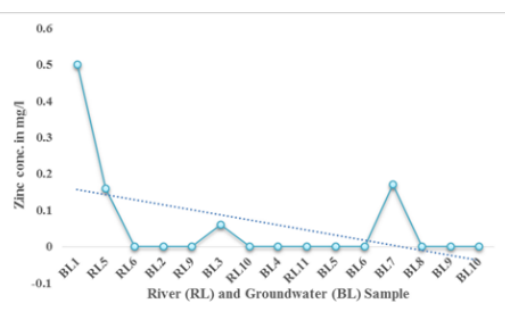

Figure 11a: Line diagram of Zinc concentration

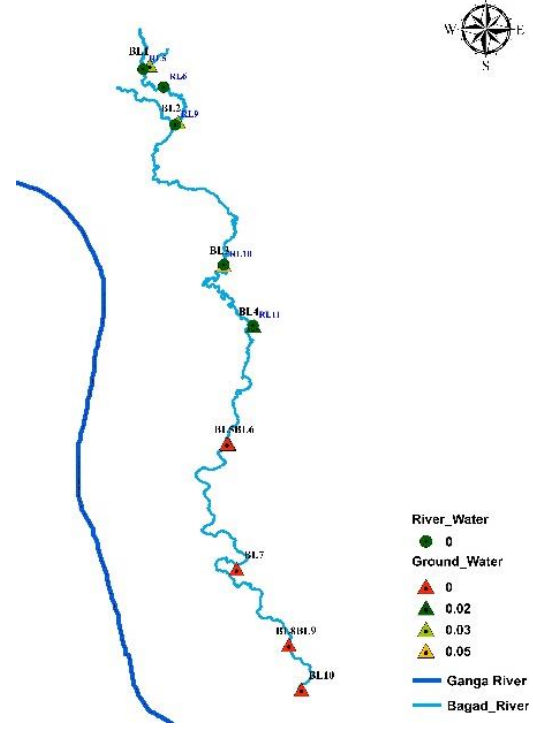

Figure 12: Lead conc. in samples

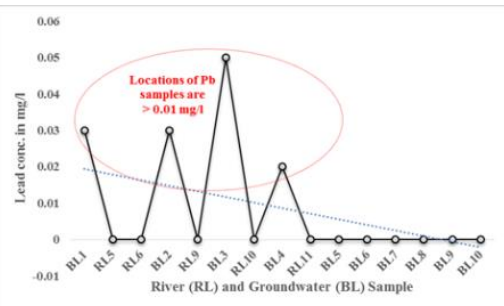

Figure 12a: Line diagram of Lead concentration

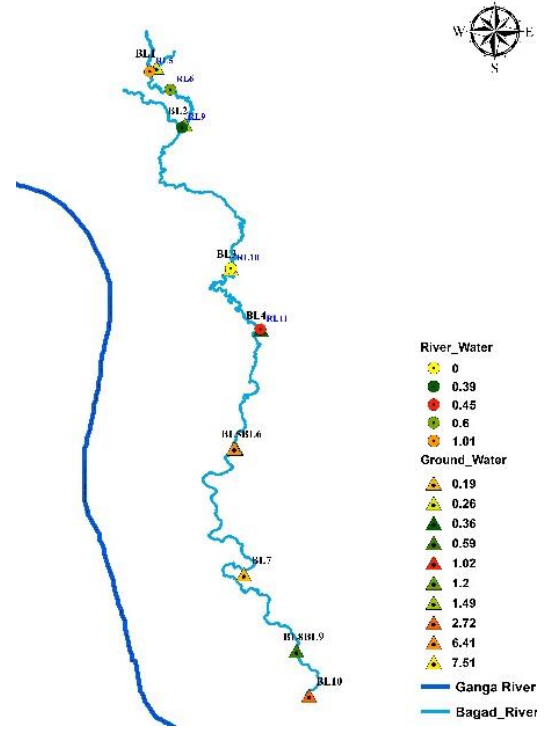

Figure 13: Iron conc. in samples

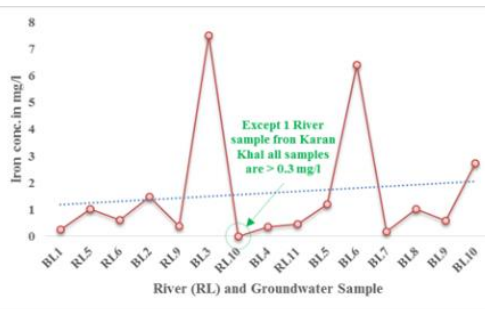

Figure 13a: Line diagram of Iron concentration

In 1976 arsenic contamination was reported in groundwater at Punjab, Haryana, Himachal Pradesh and Uttar Pradesh, Northern India (Datta and Kaul, 1976). In 1984 groundwater arsenic contamination was discovered in the lower Ganga Plain of West Bengal (Garai et al., 1984). It was only in 1995 that the arsenic situation in West Bengal and consequent suffering of people were brought to light (Chakraborti et al., 2002). In June 2002, arsenic contamination was reported in Bihar in the middle Ganga plain at the same time apprehended contamination in Uttar Pradesh lying in middle and upper Ganga plain (Sad Ahamed et al., 2006).

During a survey from December 2003 to January 2004, Sad Ahamed et al., 2006 further found arsenic contamination in groundwater at 25 percent of 698 hand tube wells from 17 villages 
of the Sahebganj district of Jharkhand in the middle Ganga plain. Similarly, University of Delhi and Jawaharlal Nehru University found groundwater arsenic in Paurara Ahtmali village of Gajraula with $0.07 \mathrm{mg} / \mathrm{l}$, which is beyond the permissible limit $(0.05 \mathrm{mg} / \mathrm{l})$ of Indian standard (BIS: 2012) (Figures 9 and 9a). Several studies (Concha et al., 1998) have shown that children are at higher risk of arsenic exposure. Chronic arsenic exposure causes a characteristic pattern of dermal effects that might start with melanosis (pigmentation) to keratosis and hyperkeratosis (Mandal et al., 1996). It has been noticed that when keratosis and melanosis appear together, they point to arsenical toxicity. Many studies of the detailed skin lesions due to arsenic concentration have been discussed before (NRC, 1999 and 2001). As there are several diseases mimicking arsenic dermatosis, care should be taken in confirming the arsenical effect (Saha, 2003).

Manganese $(\mathrm{Mn})$ tends to be adsorbed on to the clay, organic matter, freshly precipitated hydrated iron oxides, aluminates, silicates and calcite (Mehrotra and Mehrotra, 2000). In the present investigation, Mn content in groundwater ranged from 0.02 to $1.63 \mathrm{mg} / \mathrm{l}$ (Figure 10), with 90 percent of $\mathrm{Mn}$ concentration in samples beyond the permissible limit (0.02 mg/l) (BIS: 2012) (Figure 10a). The concentration of Zinc $(\mathrm{Zn})$ in groundwater of the study area varies from BDL to $0.5 \mathrm{mg} / \mathrm{l}$ (Figure 11), and all samples are below the permissible limit (15 mg/l) of Indian standard (BIS: 2012) (Figure 11a).

Agricultural activity is no major source for low concentration of $\mathrm{Zn}$ in the groundwater of the study area. Further, the concentration of Lead $(\mathrm{Pb})$ and Iron $(\mathrm{Fe})$ ranged from BDL to 0.05 and 0.19 to $7.51 \mathrm{mg} / \mathrm{l}$ in the groundwater samples, respectively (Figures 12 and 13). The same percent of $\mathrm{Fe}$ and 40 percent of $\mathrm{Pb}$ (1.5 mg/l, BIS: 2012) were detected in groundwater samples from Tigriya Khadar, Agroula Kalan, Karan Khal, Shakrouli, Shakargadhi, Tarauli, Gangeshwari and Paurara Ahtmali villages (Figures $13 \mathrm{a}$ and $12 \mathrm{a}$ ). The concentration of $\mathrm{Fe}$ in groundwater is six times higher than the permissible limit $(0.3 \mathrm{mg} / \mathrm{l})$ of the Indian standard for Fe (BIS: 2012). A comparison between concentration of trace elements in groundwater samples shows the abundance in the order of $\mathrm{Fe}(10)>\mathrm{Mn}(10)>\mathrm{Pb}(4)>\mathrm{Zn}(3)>\mathrm{As}(1)>\mathrm{Cu}(\mathrm{BDL})>\mathrm{Cr}(\mathrm{BDL})>$ $\mathrm{Ni}(\mathrm{BDL})>\mathrm{Cd}(\mathrm{BDL})$, indicating lithogenic origin of Fe in groundwater in the study area (Jiban Singh et al., 2017).

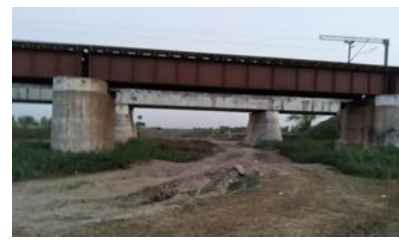

Photo 1: Shahbazpur Dor (RL1)

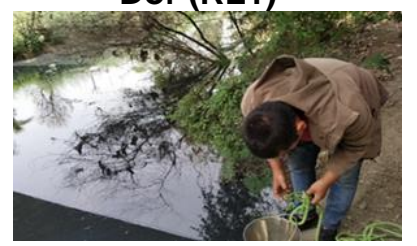

Photo 5: Tigriya Khadar (RL5)

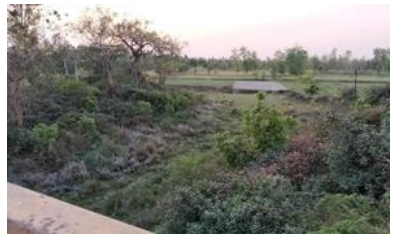

Photo 2: NH9, Khyalipur (RL2)

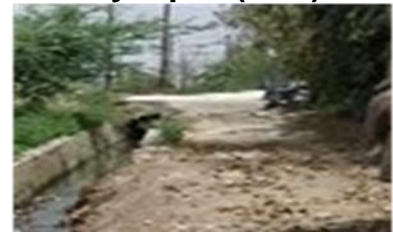

Photo 6: Tigriya Khadar (BL1)

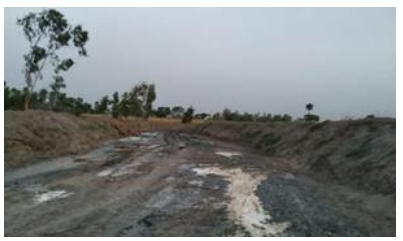

Photo 3: Shahbazpur Dor (RL3)

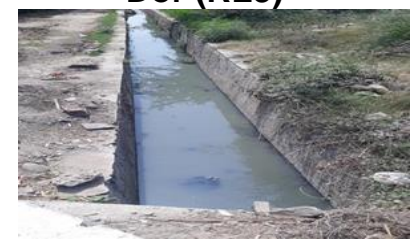

(Photo 7: Tigriya Khadar (DL1)

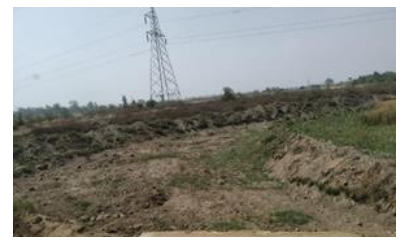

Photo 4: Tigriya Khadar (RL4)

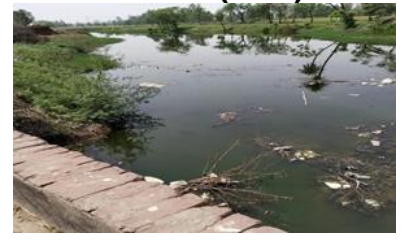

Photo 8: Sultanpur Ther (RL6) 


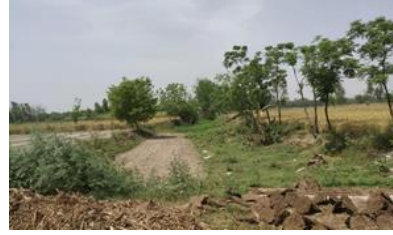

Photo 9: Sultanpur

Ther (RL7)

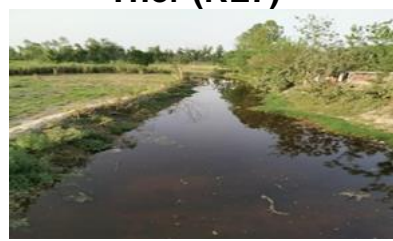

Photo 13: Karan Khal

(RL10)

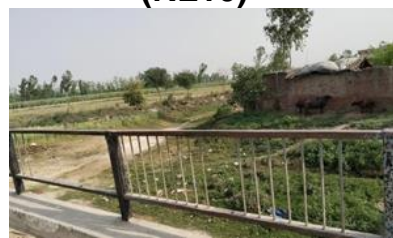

Photo 17:
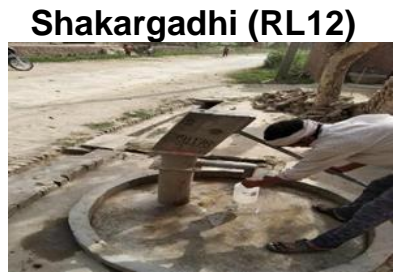

Photo 21: Tarauli

(BL7)

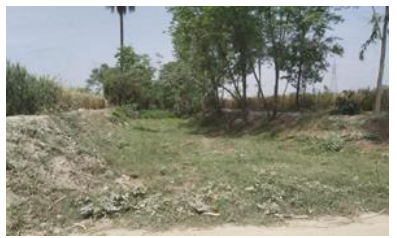

Photo 10: Sultanpur Ther (RL8)

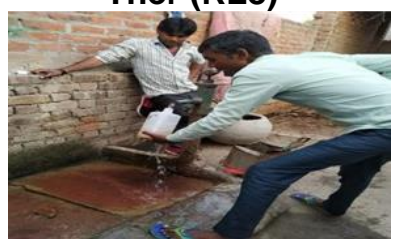

Photo 14: Karan Khal

(BL3)

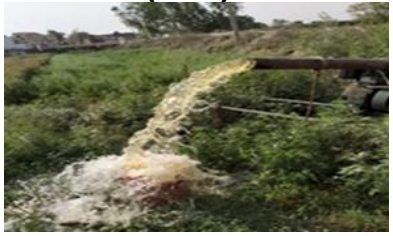

Photo 18:

Shakargadhi (BL5)

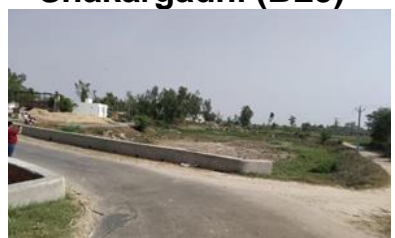

Photo 22:

Gangeshwari (RL14)

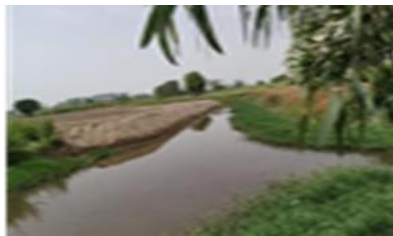

Photo 11: Agroula Kalan (RL9)

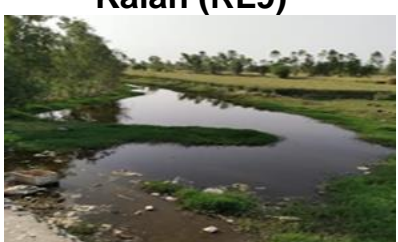

Photo 15: Shakrouli

(RL11)

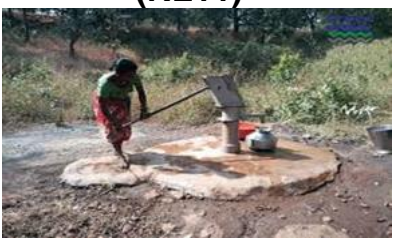

Photo 19:

Shakargadhi (BL6)

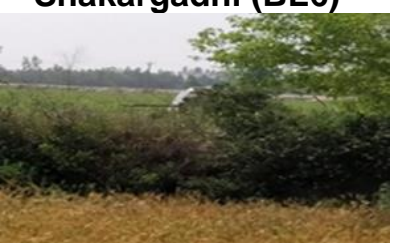

Photo 23:

Gangeshwari (BL8)

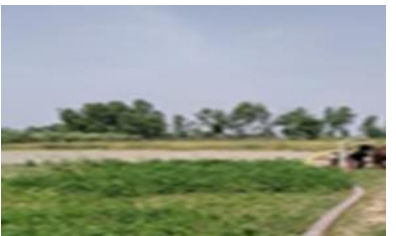

Photo 12: Agroula Kalan (BL2)

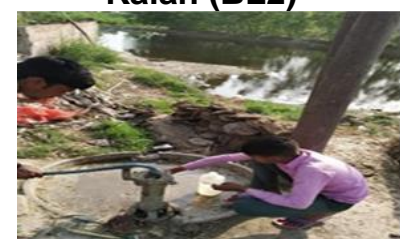

Photo 16: Shakrouli

(BL4)

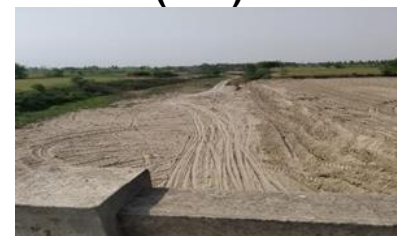

Photo 20: Tarauli

(RL13)

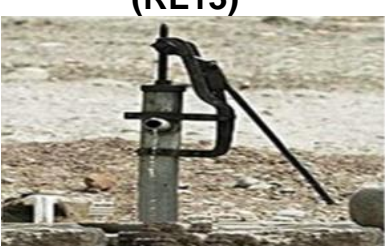

Photo 24:

Gangeshwari (BL9)

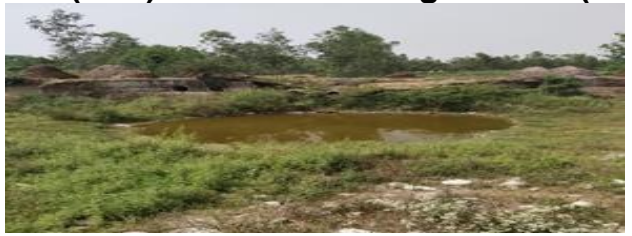

Photo 25: Paurara Ahtmali (RL15)

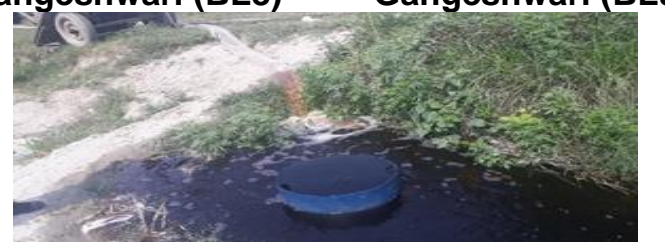

Photo 26: Paurara Ahtmali (BL10)

\section{Conclusion}

Bagad River is converted into an open drain carrying mixed effluent from industrial, agricultural and domestic discharges. Out of 15 sampling locations of the River, five locations were found stagnant and the remaining locations were found dry for the last 25 years. The $\mathrm{pH}$ values of the river water and groundwater samples were found slightly acidic to neutral, and 80 percent of groundwater hardness is greater than the total alkalinity indicated the presence of only noncarbonate or "permanent" hardness, confirmed that industrial activities cause hardness of groundwater. TDS concentration of the river water is categorized as 100 percent brackish cum saline water (TDS $>3000 \mathrm{mg} / \mathrm{l}$ ) and 70 percent of the groundwater samples which are beyond the acceptable limit $(500 \mathrm{mg} / \mathrm{l})$ for drinking purposes. BOD concentration in River water and groundwater is directly proportional to Colour and TDS, which shows the groundwater contaminated by industrial activities in the study area. $\mathrm{NO}_{3}{ }^{-}$concentration in groundwater is much higher than the River suggested leaching from industrial activities. Groundwater Arsenic concentration $(0.07 \mathrm{mg} / \mathrm{l})$ at Paurara Ahtmali village is beyond the permissible limit $(0.05 \mathrm{mg} / \mathrm{l})$ of Indian standards. Further, the comparison between concentration of trace elements in Journal of Global Resources, July 2021, Volume 07 (02) Jiban Singh M, Parveen Garg and Vijay Goel Page 64 | 13 
groundwater samples shows the abundance in the order of Fe (10) > Mn (10) > Pb (4) $>\mathrm{Zn}(3)>$ As $(1)>\mathrm{Cu}(\mathrm{BDL})>\mathrm{Cr}(\mathrm{BDL})>\mathrm{Ni}(\mathrm{BDL})>\mathrm{Cd}(\mathrm{BDL})$, indicating lithogenic origin of $\mathrm{Fe}$ in groundwater. Accordingly, groundwater regime of Bagad River is destroyed through industrial activities and become unfit for the use of drinking purpose.

\section{References}

1. APHA, (2005). Standards methods for the characteristics of water and wastewater. $21^{\text {st }}$ Ed. Washington DC: American Public Health Association.

2. Ashwani, K. T and Abhay, K. S., (2014). Hydrogeochemical Investigation and Groundwater Quality Assessment of Pratapgarh District, Uttar Pradesh, Journal Geological Society of India, 83, pp. 329-343.

3. Basavarajappa, H. T and Manjunatha, M. C., (2015). Groundwater Quality Analysis in Precambrian Rocks of Chitradurga District, Karnataka, India using Geo-informatics Technique. 4, pp. 1354-1365.

4. BIS, (2012), Drinking water specifications, Second Revision.

5. Concha, G., Nermell, B and Vahter, M., (1998). Metabolism of inorganic arsenic in children with chronic high arsenic exposure in northern Argentina. Environ Health Prospect, 106(6), pp.355-359.

6. Datta, D. V and Kaul, M. K., (1976). Arsenic content of tube well water in villages in northern India. A concept of arsenicosis. J Assoc Phys India, 24, pp.599-604.

7. Deshmukh, D. S and Karanth, K. B., (1973), Int. Symp, pp. 1-8.

8. Drever, J. J., (1982). The geochemistry of natural waters, Prentice-Hall Inc., Engle word, pp. 388.

9. Freeze, R. A and Cherry, J. A., (1979). Groundwater. Prentice-Hall, Englewood Cliffs.

10. Fetter, C.W., (1990). Applied Hydrogeology. $2^{\text {nd }}$ Edn. CBS Publishers and Distributors, New Delhi, pp. 592.

11. Garai, R., Chakraborti, A. K and De, S. B., (1984). Chronic arsenic poisoning from tube well water J Ind Med Assoc, 82(1), pp. 34-35.

12. Greenwood, W. J and Buttle, J. M., (2020). Controls on depression-focused recharge during spring snowmelt on the Oak Ridge's Moraine, southern Ontario, Canada. CATENA, 184, pp.104-241.

13. Handa, B. K., (1986). Trace Elements Content of Groundwater in the Basaltic Rocks in Some Parts of Indian Peninsula', In K. B. Power and S. S. Thigale (eds), Hydrogeology of Volcanic Terranes, University of Poona, Pune, pp. 83-104.

14. Jain, C. K., Bandyopadhyay, A and Bhadra, A., (2010). Assessment of ground water quality for drinking purpose, District Nainital, Uttarakhand, India. Environmental Monitoring and Assessment, 166, pp. 663676.

15. Jiban Singh, M., Davis, D., Somashekar, R. K. and Shivanna, K., (2012). Influence of sewerage network, using radiogenic isotope tritium. J. Sci. Egg. Tech. 5(2), pp. 88-95.

16. Jiban Singh, M., Biswas, M. K., Suneel Dave and Akolkar, A. B., (2017). Study of Groundwater Salinity in Few Districts Adjoining River Ganga in Uttar Pradesh - A Case Study, Int. J. Curr. Res. Biosci. Plant Biol. 4(9), pp. 29-41., ISSN: 2349-8080.

17. Kumar, R., Singh, R. D and Sharma, K. D., (2005), Water resources India. Curr Sci. 89, pp.794-811.

18. Mandal, B. K., Roy Chowdhury, T., Samantha, G., Basu, G. K., Chowdhury, P. P and Chanda, C. R., (1996). Arsenic contamination in groundwater in seven districts of West Bengal, India - the biggest arsenic calamity in the world. Curr Sci., 70, pp.976-786.

19. Mehrotra, P and Mehrotra, S., (2000). Pollution of Groundwater by Manganese in Hindon-Yamuna Doab (Noida area) District, Ghaziabad', In Proceedings of the International Seminar on Applied Hydro geochemistry, Annamalai University, pp. 106-112.

20. Mohit Tyagi, Swapnil Rai, Ashwani Kumar, Ashwani Yadav and Hariom Tyagi, (2015). Assessment of Ground Water Quality of Gajraula Industrial area of Uttar Pradesh, India, International Journal of Scientific Research and Education, 3(4), pp. 3265-3271.

21. Nasrullah, Raffia Naz, Hamida Bibi, Mudassar Iqbal, M and Ilyas Durrani, (2006). Pollution Load in Industrial Effluent and Ground Water of Gadoon Amazai Industrial Estate (GAIE) Swabi, Nwfp.

22. NGWA, (2020). Dissolved Mineral Sources and Significance, 601 Dempsey Road Westerville, Ohio, pp. 43081-8978, National Ground Water Association, USA.

23. Nordstrom, P. L., (1987). Groundwater resource of the antlers and Travis peak formations in the outcrop area of North Central Texas. Texas Water Development Board Report, 298, pp. 280.

24. NRC, (1999) Arsenic in drinking water Washington. USA: DC: National Academy Press; National Research Council.

25. NRC, (2001) Arsenic in drinking water Washington. USA: DC: National Academy Press; National Research Council.

Journal of Global Resources, July 2021, Volume 07 (02) Jiban Singh M, Parveen Garg and Vijay Goel Page 65 | 13 
26. Obasohan, S., Oransaye and Obano, E. E., (2006). Heavy metal concentration in Malapterurus electricus Chrysichthys nigrodigitatus from Ogba River in Benin City, Nigeria. Afr. J. Biol., 5(10), pp. 974-982.

27. Prasnath, S. V. S., Magesh, N. S., Jitheshlal, K. V., Chandrasekar, N and Gangadhar, K., (2012). Evaluation of groundwater quality and its suitability for drinking and agricultural use in the coastal stretch of Alappuzha District, Kerala, India. Applied Water Science, 2, pp. 165-175, DOI: 10.1007/s13201-012-0042-5.

28. Ranjit, S. A. J and Ajit, K. T. T., (2004). Water quality analysis of drinking water resources in selected villages in Tirunelveli district. Indian Journal of Environmental Protection, 24, pp. 48-52.

29. Ravikumar, P., Somashekar, R. K and Angami, M., (2010). Hydrochemistry and evaluation of groundwater suitability for irrigation and drinking purposes in the Markandeya River basin, Belgaum District, Karnataka State, India. Environmental Monitoring and Assessment in press.

30. Reimann, C., Bjorvatn, K., Frengstad, B., Melaku, Z., Teklehaimanot, R and Siewers, U., (2003). Drinking water Quality in the Ethiopian section of the east African rift valley I-data and health aspects. Sci. Total Environ. 311, pp.65-80.

31. Shailaja Tripathi, (2020). NGT brings strict conditions for commercial use of ground water, Jagaran Josh, July 29, 11:20 IST.

32. Sad Ahamed, Mrinal, K. S., Amitabva Mukherjee, Amir Hossain, M., Bhaskar Das, Bishwajit Nayak, Arup Pal, Subhas Chandra, M., Shyamapada Pati, Rathindra Nath Dutta, Garga Chatterjee, Adreesh Mukherji Rishiji Srivastava and Dipankar Chakraborti, (2006). Arsenic groundwater contamination and its health effects in the state of Uttar Pradesh in upper and middle Ganga plain India: A serve danger, Sc. of the total Env. 370, pp. 310-322.

33. Shankar, B. S., Balasubramanya, N and Reddy, M. T. M., (2008). Impact of industrialization on groundwater quality - a case study of Peenya industrial area, Bangalore, India. Environmental Monitoring and Assessment, 142, pp. 263-268.

34. Vinod, K. S., Devendra, S. B., Ankur Sarswat and Dinesh Mohan, (2012). Groundwater quality assessment in the village of Lutfullapur Nawada, Loni, District Ghaziabad, Uttar Pradesh, India, Environ Monit Assess., 184, pp. 4473-4488.

35. WHO/UNICEF, (2004). Meeting the MGD drinking water and sanitation target: a mid-term assessment of progress. WHO, Geneva. 